\title{
Literature Qur'an in Indonesia: Tafsir Al-Qur'an H. Zainuddin Hamidy And Fachruddin HS (Has Analysis Of The Philological Approach)
}

\author{
Sayyida $^{1}$, Kusmana ${ }^{2}$, Eva Nugraha $^{3}$, Hamka Hasan $^{4}$, Yudi Setiadi $^{5}$, \\ Rahman Ahdori ${ }^{6}$ \\ \{sayyida.shalihah14@mhs.uinjkt.ac.id¹,kusmana@uinjkt.ac.id², eva.nugraha@uinjkt.ac.id², \\ hamka.hasan@uinjkt.ac.id ${ }^{4}$, yudi.setiadi@uinjkt.ac.id ${ }^{5}$, sahabatrahman2014@gmail.com ${ }^{6}$ \} \\ Syarif Hidayatullah State Islamic University of Jakarta, Indonesia ${ }^{123456}$
}

\begin{abstract}
The interpretation of the Al-Quran and its literature throughout Indonesia in the 20th century experienced significant development and progress very rapidly since it was started by Mahmud Yunus in the 1940s. The tafsir writer wrote the interpretation for the advancement of Muslims in Indonesia. at least there are interpretations written in Indonesian that are used for reading material for the people of this country. Because many Indonesian Muslims do not deepen and understand the al-Qur'an which is originally Arabic. After the interpretation of Mahmud Yunus' work, then Ahmad Hasan interpreted the Qur'an with his interpretation of Al-Furqan, namely in 1940. Then, H. Zainuddin Hamidy and H. Fachruddin HS wrote their tafsir works with a better arrangement. There are many interesting sides to this interpretation. In a paper on this interpretation work, the speaker will discuss one of the commentators in Indonesia, the more popular one by the name of Haji Zainuddin Hamidy and his friend Fachruddin HS.
\end{abstract}

Keywords: Interpretation, Fachruddin, Zainuddin.

\section{Introduction}

Padang City, West Sumatra in 1906, H. Fachruddin HS Datuk Majo Indo, in Sit Tujuh Batur, Limapuluh Kota district was born a child of a very popular and respected scholar, namely, H. Husein Tuanku Khatib, his mother was named Hj. Putiah Fatimah and her brother named Makinuddin HS.

H. Fachruddin HS Dt Majo Indo is active in the Sumatran Thawalib student association and serves as Chairman of the PERMI (Indonesian Muslim Association) Payakumbuh Kab. 50 Cities.

\subsection{Background of Fachruddin Hs.}

Within the family, Fachruddin Hs. When he was a child, he received attention and appreciation from his family about his goals in the future. Fachruddi Hs wanted to become a scholarly father or a great scholar. So that in order to achieve this goal he needed to explore knowledge, both Islamic religious knowledge and general science, for that he studied at various schools both formally and informally. 
While studying in Bandar Dalam, he and his friends began to gain lessons and insights about world knowledge from two dispatched magazines, namely Islamic magazines with Arabic writing named Al-Iman and Al-Basyir wan Nadzir, Al-Iman Magazine was published by Religious Madrasah in Padang Japan District 50 Cities.

After a year of studying at Bandar Dalam, Fachruddin Hs moved to Batang Tabit, studying with Tuanku Mudo Hamzah. After studying there for two years, he moved to study at Sinchin, a madrasa led by Tuanku Mudo Ahmad Sack, who is usually called Tuan Karung. While studying there besides studying religion and science, he also read various magazines and newspapers to find out about events in the world and in Indonesia.

The knowledge that he has, of course, is based on a background of thought which is influenced by either a figure or a history of education. One of which is:

1. Akidah and Islamic law, are two main points contained in Islamic teachings. According to him, faith means things related to belief, faith, and belief. His thoughts are based on the thoughts of Mahmud Syaitut, which are stated in his various books.

2. The book of Mental Guidance Al-Qur'an which he composed contains 32 themes related to the mental development of a Muslim by looking at the Qur'anic ayar and providing explanations on each of the related issues so that everyone can take a lesson. His explanation was based on several books of interpretation which influenced one of them being Ahmad Mustafa Maraghi, Sayyid Qutb, Ibn Kathir, and so on.

\subsection{Curriculum Vitae of H. Zainuddin Hamidy}

Haji Zainuddin Hamidy was born in Koto Nan IV Payakumbuh on February 8, 1907. The son of Abdul Hamid and Halimah. He is said to have several unique characteristics, such as his hobby of playing football, even according to one of his students, H. Haffash Shamah, when he does not teach he often plays football with his students. In addition, Buya Zainuddin Hamidy called his students as ustadz. This motivated them to the point that many became scholars. Buya Zainuddin Hamidy also has a habit that makes a distinctive impression on the hearts of his students, namely when teaching the hadith, if he forgets, he rubs his face from forehead to chin, and when he removes his hand from his chin he immediately mentions the hadith he had previously forgotten (mentioning hadith starting from sanadnya). Other habits, as told by his urid Dr. Nukman MA, Buya Zainuddin Hamidy never saw a book while teaching. Even though he still carries a book, the book is only held and not open.

About Buya Zainuddin Hamidy, Buya Hamka said: "Ustadz Syekh Haji Zainuddin Hamidy is a simple person. The conversation from his mouth was one on one, not much. When people talk about useless things, they just keep quiet. When people ask questions, he answers with a smile. A smile that contains a thousand and one meanings ..."

playing football is his favorite sport. Even this hobby of playing football was carried over until he was an adult. H. Haffash Shamah, his student said that if Buya Zainuddin did not teach, he would play soccer with his students and the youth around the pesantren.

H. Zainuddin Hammidy's educational background and thoughts

\subsubsection{Formal and Non Formal Education}

Besides ordering Zainuddin Hamidy, he also took formal education. In the government school in Payakumbuh, he studied for five years. Then, he continued his studies at Darul Funun al-Abbasy Padang, Japan. 
His love for science is seen in him always learning anytime and anywhere. During the school holidays from Darul Funnun, he went to meet my master Ahmad Karung in Batang Tabik, for the Koran (Learning Al-Qur'an). Here, Zainuddin met Fachruddin Hs. Dt, Majo Indo whose biography is one of his closest friends in cooking and writing.

\subsubsection{Studying to Mecca}

Shaykh Abdullah Abbas, head of Madrasah Darul Funun al-Abbasy, ordered Zainuddin to be his successor at Darul Funun. However he went to Mecca to study in 1927, his wife, Rahmah was abandoned. He studied at Ma'had Islamic and was the first person from Indonesia to study. After five years of studying, he then returned to his homeland in 1932.

\subsubsection{Sanad Tahfizh}

Dr. Nukman revealed that in the past, scientific culture in Minangkabau was one of them before studying religion, one had to learn the Qur'an first.

Zainuddin Hamidy after returning from Mecca, he is known as a memorizer of the Qur'an and an expert on hadith. Get the title muhaddits. Students who are known to memorize the Qur'an are: 1) Zubir Said, an expert reciter ,and hafiz, 2) Arius Saikhi, a clever man and an expert in reckoning, 3) Abdurrahman Zainuddin, Zainuddin's own son, a professor at the University of Indonesia (UI) and an al-Qur'an memorizer.

Buya Zainuddin is an al-Qur'an memorizer who is very skilled in the field of ulumul Qur'an, he is very concerned about the interpretation of the al-Qur'an and the development of the science of hadith in Indonesia.

The science that he has, of course, is based on a background of thought that is influenced by either a figure or a history of education that he has taken. The following is the background of thought that influenced his scholarship which is reviewed from several papers:

1. The Mustahalah Hadith Book which became his guide when teaching hadith at the Training College, Pakayumbuh, and PGA Bukit Tinggi. Is a book about the science of hadith in the creed by Imam Abu Muhammad an-Naisaburi, with the title Ma'rifatul 'Ulumil Hadith. In the book describes the science of hadith merayah, which is the science that discusses the rules for knowing things (conditions) sanad, mind, ways of receiving and conveying hadith the characteristics of hadith and the like.

2. In the next section he translated more of several well-known hadith books. In his remarks, he first saw the problems that occurred and the needs that existed in society and also aimed to uphold Islamic law in Indonesia.

\subsection{Zainuddin Hamidy's work}

Shaykh Zainuddin Hamidy is known to have far-reaching views for the future. Apart from being active in teaching, politician, organizer, and hadith expert, he is also a book writer. However, during the Dutch and Japanese times, the book was lost. The following is his written work: 
1. The translation of the book al-Qur'an Karim, is the Tafsir Al-Qur'an which was written with Fakhruddin HS according to the periodization of tafsir in Indonesia, the interpretation in the $1963 \mathrm{~s}$ was the fourth generation in the 20th century

2. Translation of the book Sahih Bukhari, co-written with Darwis Z and Fakhruddin HS in 2006 is the second publication year.

3. Translation of the Hadith Arba'in book, the book of tauhid and Musthalahul Hadith, these books become the basis for teaching the science of hadith.

\section{Text formatting}

\subsection{Philological Data of Qur'anic Interpretation}

Mafri Amir explained that:

"This philological data is written from a collection of commentaries in the Ushuluddin Faculty Library at UIN Syarif Hidayatullah Jakarta, namely:

- Name: Tafsir Qur'an Original Text - Translation - Full Description of $30 \mathrm{Juz}$

- Compiled by H. Zainuddin Hamidy \& Fachruddin Hs.

- Language of the Book: This book uses Indonesian in the past

- Publisher: from Widjaya Djakarta

- Year of publication: in 1967

The systematics of writing applied to the Qur'anic Tafsir are as follows:

- The interpretation of this book is included and explained in the footnote section

- Verse writing side by side with the translation

- Writing the interpretation in accordance with the order of the Qur'an, starting from the essence of Al-Fatihah to Al-naas

- There are several tables of contents writing. Such as writing a table of contents according to juz, a table of contents according to alphabetical order, and there is also writing a table of contents only for the most important/thematic parts of the letter.

This book has been published 4 times, the first printing in 1955, the second printing in 1962 , the third printing in 1963 , the fourth printing in 1967 . What is being examined is the fourth edition.

The length of this book is $28 \mathrm{~cm}$ high and $25 \mathrm{~cm}$ wide. Turning to the contents of the book, this is in a hardcover condition, while the paper used is newsprint that has faded color, there are lots of blots and the paper starts to tear. In general, during his period of time, the interpreting scholars in Indonesia used Arabic-Malay, while in this book he used Indonesian with perfected spelling. 


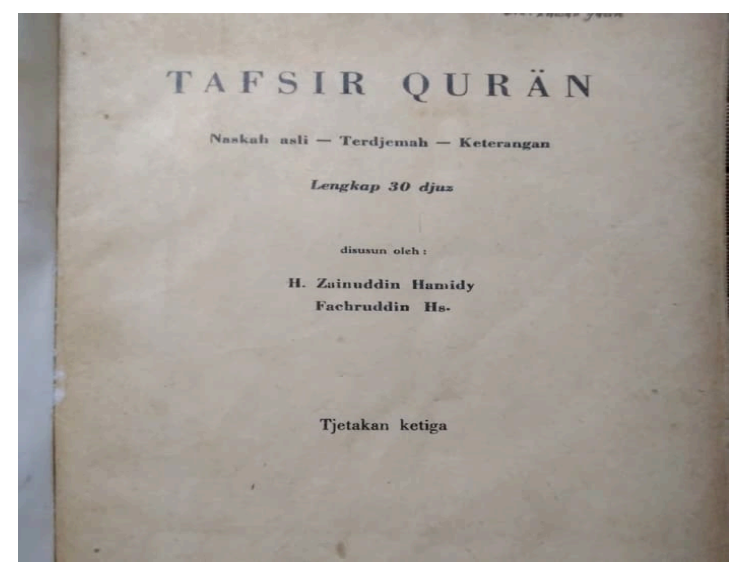

Fig. 1. Architecture of a typical wireless sensor node.

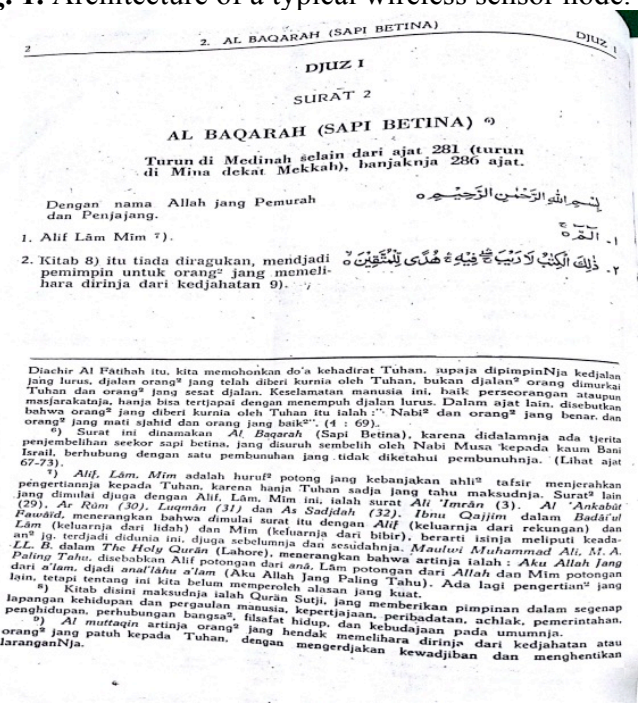

Fig. 2. Architecture of a typical wireless sensor node. 


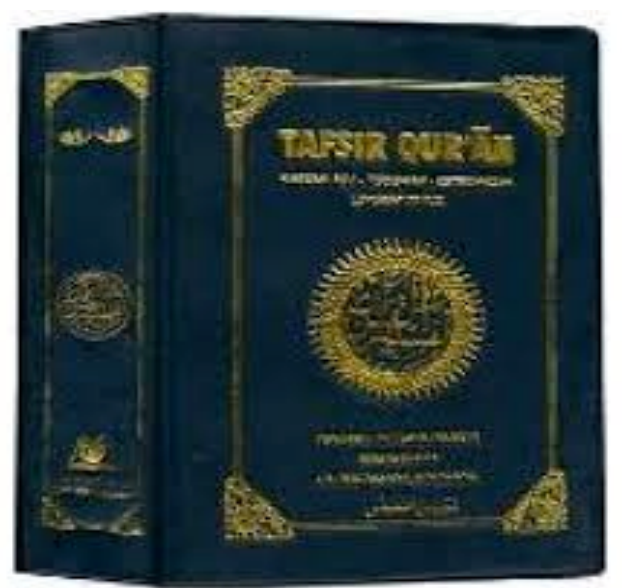

Fig. 3. Architecture of a typical wireless sensor node.

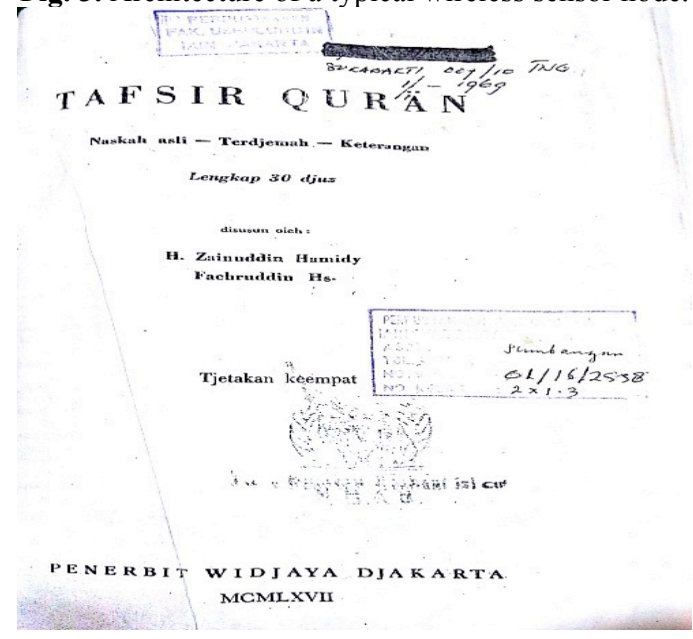

Fig. 4. Architecture of a typical wireless sensor node.

\subsection{Background for writing the Qur'anic interpretation}

When viewed from the background of writing this interpretation is a contribution to the religion of Islam as in the book's introduction:

"The compilation of this Qur'anic interpretation is not an easy matter, but rather heavy and difficult work. And this writing requires a study that is several years old and its preparation requires sufficient effort, thought, and time. Alhamdulillah, this long and hard work has been completed as a contribution and service to the height of our religion.

\subsection{Characteristics of Interpretation}

The author does not interpret the entire verse but only interprets the parts of the verse which according to the interpreter writer it is important to interpret and interpret it only 
globally. This commentary book does use Indonesian which is not standardized and does not match the Perfected Spelling.

At the beginning of the book, there are remarks and an introduction from Sheikh Sulaiman ar-Rasuli Bandung, in 1956 a speech from Sheikh Ibrahim Musa Parabek, and previously who wrote 3 in 1953, Haji Agus Salim. This interpretation was completed in 1953. Then, the authors Zainuddin Hamidy and Fachruddin HS wrote a list of letters according to the Latin alphabet and the end of the book Zainuddin Hamidy and Fachruddin HS included the content instructions, with the alphabet, a list of letters, and the most important contents.

\subsection{Types of Tafsir (Naw'u at-Tafsir)}

In writing the interpretation of the Koran, the author does not explain in detail in his commentary book. ijtihadi.

\subsection{Method (Tariqah)}

The author uses the ijmali method in interpreting words. The author quotes commentary books such as Tafsir al-Kabir, Tafsir Fathul Qadir, Tafsir Ruhul Ma'ani, Tafsir al-Qur'an Nul 'Azim, Tafsir al-Manar, and Tafsir al-Jawahir, The Holy Qur'an works A. Yusuf Ali and also by Maulvi Muhammad Ali MA, and The Meaning Of The Glorious Koran by Muhammed Marmaduke Pickthall, etc.

When viewed from a systematic point of view, the writer uses the tahlili method, because in order according to the tartib verses and letters in the al-Qur'an, it begins with the letter alFatihah and ends with the letter al-Naas.

\subsection{Pattern (Lawn)}

Although this interpretation does not lead to a lawn (pattern), the discussion leads to a lawn (pattern), namely social (Adabi-Ijtima'i).

\subsection{Source (Mashodir)}

The source of the written hadith, Sahih al-Bukhari, Sahih Muslim, and other hadith books. Among them is al-Mufradat Fi'qharibil Qur'an by al-Asfahani, Mu'jam Gharibil Qur'an by Muhammad Fuad Abdul Baqi, and Mu'jam al-Qur'an by Abdul Rauf al-Misry. This interpretation is supported by many scholars such as Haji Agus Salim and Syekh Ibrahim Musa.

\subsection{Separation Technique (Al-Qism or Al-Majmu'ah)}

He uses the Al-Majmu'ah technique (one discussion). When viewed from a systematic point of view.

\subsection{Interpretive Steps}


The author in writing this book used a mushafi tartib containing the number and name of the surah, the number of verses from which the Makkiyah-Madaniyyah descended. also translated the name of the letter.

\subsection{Examples of Interpretation} Nuzul

The following is an example of interpretation by referring to the hadith and its Sababul

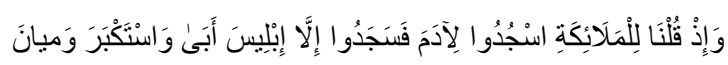

"And when We said to Malikat: You submit to Adam. Then they submit, apart from the devil (footnote no: 28); he is reluctant and proud of himself, and he is one of the unbelievers. " (Surah Al-Baqarah: 34)

\section{Thetoric}

Thomas De Quincey discloses for fraudulent purposes like this:

"The other applies itself more specifically to a definite purpose of utility, viz. fraud. "(Covino, W.A and Jolliffe, D.A. 1995: 3)

Modern rhetoric scientific is used as a joint for worship. The principle of disclosure to get a balanced impression. That is, the concept must be connected with the liyubayyina concept which is civilized and has morals. It is not enough just to use rhetoric as an example of the highest intellect as expressed in Aristotle's ethos.

The rhetorical ethos shows revelation as in surah al-Ahzab (33) verse 21 and surah alQalam (68), verse 4 as follows: II

And indeed Allah's Apostle is a good role model for you and for those who expect to meet Allah and the next day and who remember Allah as much as possible.

(H. Zainuddin Hamidy and Fachruddin Hs., Quran Tafsir: 1991: 610)

$\mathrm{u}$ And you actually have high character.

(H. Zainuddin Hamidy and Fachruddin Hs., Quran Tafsir: 1991: 845)

The rhetorical ethos in the example of the verse above shows the Prophet to be a role model for us. In all of our work, everything begins with intention. And that intention lies in the heart. if our heart is broken, then the whole body is damaged. Therefore intention becomes a path to charity. Here the Malay language can be seen in the very impressive art of expression.

\subsection{Semiotic}

The Malay language associated with the Malay sign system is not just semiotic which Saussure and Peirce express about the concept. The system rejects the concept of arbitrariness 
contained in the Saussure and Peirce Triadic Models. All problems regarding the refusal of arbitrariness can be seen from the semiotic perspective, namely hujah aqli and hujah naqli. Hujah aqli shows in concrete to abstract order. Hence, the phenomena of various symbols have the same meaning. And the naqli hujah can also be rephrased with the Surah Ar-Rum and Al-Hujurat the meaning of the above verse, showing signs of the greatness of Allah and to increase our worship of Allah SWT. Here are explained about the features of the concrete, abstract, and unseen. The realm in question is the afterlife. It rejects Peirce's suggestion of rejection of God. Then, absolutes regarding the matter of the truth of significance in the triadic. - Truth is still relative and necessary with the truth of revelation. Regarding the need for the widest semiotic that gets the fit of that model by trying to find Malay through its sign system, namely, language is a gift from Allah, its nature, and as a sign of His greatness. "And when We said to Malikat: You submit to Adam. Then they submit, apart from the devil (footnote no: 28); he is reluctant and proud of himself, and he is one of the unbelievers. " (Surah Al-Baqarah: 34)

\section{Conclusion}

The results of the investigators' search on Hamidy and Fachruddin in writing the al-Qur'an tafsir, this type of interpretation is an interpretation. When viewed from a systematic point of view of writing and interpretation, and seen from the method of interpretation, this work uses the tahlili method, because he writes the interpretation of the verses of the Koran in the order of verses and chapters, which begins with the beginning of Surah al-Fatihah and ends with a letter. al-Naas. Lawn (Corak) Tafsir Qur'an Karim by Zainuddin Hamidy and Fachruddin Hs can be seen from what has been illustrated from his description, namely on social lawns. Then we look at the interpretation from the systematic point of view of the writing, the separation technique, or what is also called Al-Qism, this interpretation uses the Al-Majmu'ah technique, meaning that this interpretation uses one discussion.

\section{References}

[1] M. Faisal, "Writing Interpretations In Indonesia Classical And Modern Times," J. Ilm. Teunuleh Int. J. Soc. Sci., vol. 1, no. 1, 2020.

[2] H. Federspiel, Kajian al-Qur'an di Indonesia. Bandung: Mizan, 1996.

[3] A. Bazith, “Metodologi Tafsir 'Al-Furqan Tafsir Qur’an’ (Membaca Karya A. Hassan $1887-$

1958),” Educ. Learn. J., vol. 1, no. 1, 2020.

[4] K. Huwaida, "Unsur Lokalitas Dalam Tafsîr Al-Furqân Karya Ahmad Hassan,” Institut Ilmu Al Quran (IIQ) Jakarta, 2020.

[5] M. Dalip, "Melacak Metodologi Penafsiran Mahmud Yunus Dalam Kitab Tafsir 'Quran Karim,", J. Tafsere, vol. 8, no. 1, 2020.

[6] Y. Rahmi, "Konstruksi Manhaj Akademisi terhadap Kitab Tafsir Al-Fatihah Karya Mahmud Yunus," Islam Transform. J. Islam. Stud., vol. 4, no. 2, 2020.

[7] R. Igisani, "Kajian Tafsir Mufassir di Indonesia," J. POTRET - J. Penelit. dan Pemikir. Islam, vol. 22, no. 1, 2018.

[8] A. Rouf, Mozaik Tafsir Indonesia. Depok: Sahifa Publishing, 2020.

[9] M. Shahib and M. B. Y. Surur, Para Penjaga al-Qur'an: Biografi Huffaz al-Qur'an di 
Nusantara. Jakarta: Lajnah Pentashihan Mushaf al-Qur'an, 2011.

[10] M. Amir, Literatur Tafsir Indonesia. Tangerang Selatan: Mazhab Ciputat, 2013.

[11] H. Z. Hamidy and F. Hs., Tafsir Qur'an. Klang: Klang Book Centre, 1991.

[12] W. Covino, Rhetoric: Concepts, definitions, boundaries. Boston: Allyn \& Bacon, 1995. 